NBER WORKING PAPER SERIES

\title{
UNEMPLOYMENT INSURANCE AND RESERVATION WAGES
}

Martin Feldstein

James Poterba

Working Paper No. 1011

NATIONAL BUREAU OF ECONOMIC RESEARCH

1050 Massachusetts Avenue

Cambridge MA 02138

Ju1y 1982

The research is part of the NBER study of the Government Budget and the Private Economy. Any opinions expressed are those of the authors and not those of the National Bureau of Economic Research. 
The present paper examines the reservation wages reported by a large sample of unemployed individuals in the United States in May 1976. The majority of unemployed individuals report reservation wages that are at least as high as the wage they were paid on their last job. Approximately one-fourth of all job seekers required a wage that is at least 10 percent higher than the wage on their previous job.

Our econometric evidence shows that the level of unemployment benefits relative to previous wages has a powerful effect on the individual's reservation wage. A ten percent increase in the U.I. replacement ratio increases the reservation wage by about 4 percent for job losers who are not on layoff and by somewhat less for other unemployed groups. Separate regressions to analyze the high reservation wage per se show that a ten percent increase in the U.I. replacement ratio also increases by about four percentage points the probability that an unemployed individual will require a wage increase of 10 percent or more.

These estimates imply that reducing net unemployment insurance benefits (by lowering gross benefits or by taxing unemployment benefits) could significantly lower the average duration of unemployment and the relative number of long duration spells of unemployment. Because of the non-linear response of the unemployment duration to the reservation wage, reducing a high unemployment insurance ratio by ten percentage points is likely to have a greater impact on unemployment than reducing a low unemployment insurance ratio by ten percentage points.

Martin Feldstein

Department of Economics

Harvard University

Cambridge, MA 02138
James Poterba

National Bureau of Economic Research 1050 Massachusetts Avenue Cambridge, MA 02138

(617) $868-3930$ 


\section{Unemployment Insurance and Reservation Wages}

Martin Feldstein*

James Poterba**

\section{Introduction}

The principle imperfection in modern labor markets is the downward rigidity of existing nominal wages. As a result, a decline in the marginal value product of an employee's labor is likely to cause a termorary or permanent layoff rather than a downward wage adjustment. Such separations are inefficient because they waste job specific human capital and cause employees to work at new jobs in which their productivity is lower than it would be if they renained at their previous job. 1

Although wage reductions on an existing job are rare, an employee who loses his job is likely to find that the wage on his next job is lower than the wage on the job that he lost. There are at least five reasons to expect this wage reduction: First, the original job loss is likely to have occurred because of a decline in the value of the employee's services. This may reflect a deterioration of the employee's own skills, a change in available production methods that makes existing skills less valuable, or a decline in the real price of the product that the employee produces. Second, even if there has been no

*Harvard University and the National Bureau of Economic Research.

**oxford University and the National Bureau of Economic Research.

This paper was prepared for the June 1982 Oxford conference on "Micro-Data and Public Economics", sponsored jointly by the NBER and the Social Science Research Council of Great Britain. The research is part of the NBER study of the Government Budget and the Private Economy .

${ }^{1}$ See Hall and Lazear (1982) for an analysis of the inefficiency of such separations and of the second-best character of contracts that entail such wage rigidities.

(051382) 
decline in the actual value of an employee's services, he may lose his job because his employer accumulates enough information to decide that the value of those services is below his wage. Third, as we have already noted, the change in jobs is likely to involve some loss of job-specific human capital. Fourth, a prospective employer who is not able to judge the skill level of a new employee will pay a lower wage until information accumulates. Finally, employees with substantial job tenure may receive wages that exceed the marginal value product of their labor while new employees are paid less than their marginal value product (Medoff and Abraham, 1978, and Lazear, 1981, 1982).

The actual wage on the new job depends on the job-seeker's willingrness to search and to wait. A job loser may have to wait a long time unless he reduces his reservation wage below the wage that he received on his last job. The more he reduces his reservation wage relative to his previous wage, the sooner the job loser can expect to find new work. 1

The traditional distinction between voluntary and involuntary unemployment pushes this notion to the extreme and classifies an individual as voluntarily or involuntarily unemployed according to whether or not he is willing to work at a wage that is less than or equal to his previous wage. The search theory model of unemployment ${ }^{2}$ implies that this two-way classification is less meaningful than using the individual's reservation wage as a continuous

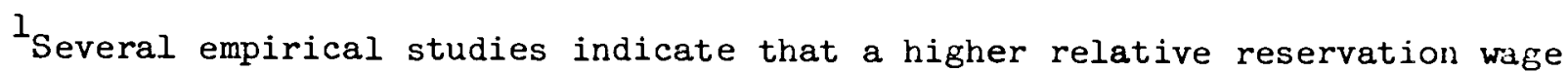
reduces the probability of leaving unemployment and becoming employed (Baron and Mellow, 1981, and Warner et al., 1980).

${ }^{2}$ See Stigler (1962) for the basic idea of the theory. A more formal model is presented in a number of places, e.g., McCall (1970), and Mortenson (1977).
} 
measure of the eagerness or reluctance of the job-seeker to accept employment. Even an individual who is willing to work for less than his previous wage will be voluntarily unemployed in the sense that he rejects wage offers below his reservation wage. Nevertheless, a comparison of the reservation wage with the wage on the last job is useful simply because the probability of finding an acceptable job is likely to decline rapidly as the reservation wage exceeds the previous wage. ${ }^{1}$

An alternative theory might replace the notion of voluntary and involuntary unemployment with a comparison of the individual's reservation wage with the socially optimal reservation wage for that individual. The socially optimal reservation wage for an individual reflects a balancing of the gains of additional job search (measured by the increase in the individual's marginal product in a better job) against the cost of that search (measured by the value of foregone production, net of the value of leisure, during the period of additional search.) The primary reason for the difference between the privately optimal reservation wage and the socially optimal reservation wage is that unemployment insurance benefits decrease the private cost of unemployment but not the social cost of unemployment. ${ }^{2}$ Because of unemployment insurance, the privately optimal reservation wage exceeds the socially optimal reservation wage and job search is inefficiently prolonged.

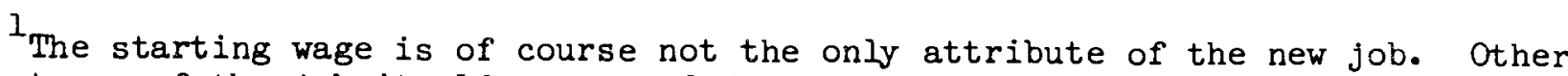
features of the job itself, expected future wage increases, pension arrangements, etc., all influence the job's attractiveness. We implicitly assume that these features do not differ between the previous job and the prospective new job and that they vary monotonically with the wage.

${ }^{2}$ The private reservation wage also reflects the income tax that reduces both the opportunity cost of unemployment and the reward for finding a better job. But if the marginal tax rate is constant, this effect is at most of secondary importance. 


$$
-4-
$$

It would be good to measure the extent to which private reservation wages exceed the corresponding social optima and to estimate the actual effect of unemployment insurance on this gap. Unfortunately, although data are available on individual reservation wages, no direct observation or calculation of socially optimal reservation wages is possible. In the present study we therefore compare an individual's reservation wage with the wage he earned on his previous job. The wage on the previous job is of interest in itself in this context and can also be interpreted as an indication of the socially optimal reservation wage.

The previous wage is likely to exceed the socially optimal reservation wage for individuals who lost their previous job. By definition, a job loser was willing to continue working for his previous employer at his previous wage. Thus the previous wage was at least equal to the individual's previous private reservation wage. Since unemployment insurance makes the private reservation wage greater than the social reservation wage, the previous wage was greater than the previous socially optimal reservation wage. Since the unemployment itself reflects or causes a fall in the distribution of potential waise offers, ${ }^{1}$ the new socially optimal reservation wage is also lower than the previous socially optimal reservation wage. Thus the previous actual waye exceeds the new socially optimal reservation wage.

The present paper examines the reservation wages reported by a large sample of unemployed individuals in the United States in May 1976. At that

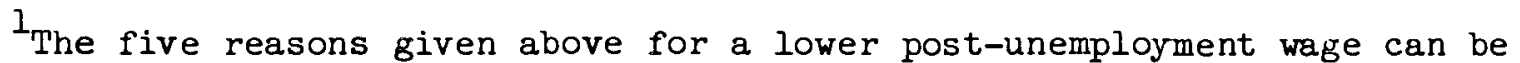
interpreted as reasons for a downward shift of the distribution of potential wage offers.
} 
time, the econond was still recovering from the recession that ended in March 1975. The overall unemployment rate of 6.7 percent indicated that substantial slack still remained in the labor market. We report information separately for those individuals who are classified as job-losers and those who report that they voluntarily quit their previous job. Specific attention is given to the relative level of unemployment insurance benefits as a determinant of the reservation wage.

A most striking finding in our analysis is that the majority of unemployed individuals report reservation wages that are at least as high as the wage they were paid on their last job. But the median reservation wage ratio $^{l}$ is less important than the substantial fraction of job seekers who require wages that are significantly higher than their last wage. The evidence presented in section 3 shows that approximately one-fourth of all job seekers require a wage that is at least 10 percent higher than the wage on their last job. Not surprisingly, individuals who voluntarily left their previous job generally report even higher reservation wage ratios. Fully 31 percent of job leavers are seeking new jobs that pay at least 10 percent more than their present wage.

Several previous studies (e.g., Baron and Mellow, 1981, and Warner, Poindexter and Fean, 1980) have noted that the mean of the reservation wage ratio or of some closely related measure ${ }^{2}$ is less than one and concluded that

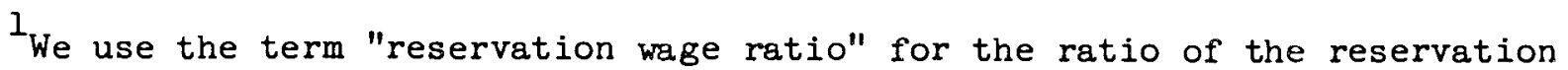
wage to the wage on the individual's last job.

2 The usual measure is the ratio of the reservation wage to the wage predicted for the individual. Section 2 discusses this ratio and the reason why it is likely to be lower than the reservation wage ratio that we analyzed.
} 
this is consistent with the theoretical expectation that unemployed individuals set low reservation wages. By looking only at the average reservation wage, these studies fail to see the large percentage of individuals who have set significantly high reservation wage ratios. Only Clark and Summers (1979) note that a significant fraction of reservation wages exceed the individuals' previous wages.

The official procedure of the U.S. Department of Labor classifies an individual as unemployed if he is not currently working and has done something in the past four weeks to find employment. No reference is made in this criterion of unemployment to the individual's reservation wage. Even someone whose reservation wage is so high that essentialy all feasible wage offers would be rejected is thus of ficially classified as unemployed. In section 4 of the present paper we use information on the individual reservation wages to adjust the official unemployment statistics. We define an adjusted unemployment rate by excluding everyone whose reservation wage is above the wage on their last job. A more conservative procedure defines an adjusted unemployment rate by excluding those with reservation wages above 1.1 times their last wage.

The primary focus of the present research is the effect of unemployment insurance on reservation wages. Section 5 of the paper summarizes previous research on this subject and discusses the specification of the reservation wage equations that we use to estimate the effect of unemployment insurance. Section 6 presents parameter estimates for these equations and section 7 discusses the implications for the expected duration of unemployment and for the probability of long spells of unemployment. There is a brief concluding section. 


\section{Data and Definitions}

Our analysis is based on a special study of the job search methods of the unemployed that was conducted by the U.S. Department of Labor in May 1976.1 A total of 4,668 persons in the Current Population Survey in May 1976 were classified as unemployed and asked to fill out a special supplementary questionnaire concerning previous work experience and earnings, current job-seeking methods and aspirations, and related questions. In many households, the form was left to be filled in later or was mailed to the unemployed person after a telephone interview. The nonresponse rate was 31 percent and resulted in a total sample of 3,238 completed questionnaires. Although there is no reason to expect a systematic bias in the sample of respondents with respect to the questions of interest in this paper, a 31 percent nonresponse rate is clearly a reason for caution in interpreting any precise numbers.

Since our interest is in the ratio of the individual's reservation wage to his or her previous wage, we have eliminated from the Department of Labor sample all those individuals who are classified as new entrants (who have no previous wage) or reentrants (whose previous wage may refer to a much earlier period). Some individuals who answered the questionnaire did not provide information about their reservation wage or their previous wage. A small group of respondents provided such extreme answers (reservation wages that were more than three times their previous wage or less than one-third of their previous wage) that we thought it best to disregard those answers as indicating that the respondents did not understand the question or were unwilling to provide an

${ }^{1}$ See Rosenfeld (1977) for a description of the survey and a copy of the questionnaire. 
answer. Our final sample contains 2,228 men and women for whom all the required data are available.

Our measure of the reservation wage was based on the following pair of questions: (1) "What kind of work were you looking for (in the period for April 18 through May 15)?" and (2) "What is the lowest wage or salary you would accept (before deductions) for this type of work?" Individuals who indicated that they were looking for more than one kind of work were asked to specify their reservation wage for the type of job that they preferred.

In our basic analysis, we compare this reservation wage to the wage that the individual describes as "the usual earnings ... before deductions" on the "last job at which you worked for two consecutive weeks or more." Individuals were also asked whether they had had a higher paying job since January 1, 1974. Approximately one-fourth of the individuals in our sample responded that they had had such a job and they were asked to specify their usual earnings on that job. We also present some analysis based on the ratio of the reservation wage to this previous highest earnings. ${ }^{l}$

Survey respondents were also asked whether they received any unemployment insurance benefits during their current spell of unemployment. Those who had received benefits were asked what their weekly benefit was. In our analysis of the effect of unemployment insurance on reservation wages, we use the ratio of this reported U.I. benefit to the highest previous wage, i.e., the highest wage on any other job since January 1974 including the last job.

\footnotetext{
${ }^{1}$ Individuals may indicate their usual earnings as a rate per hour, per week, per month or per year. As long as the unit is the same for the reservation wage and the previous wage, the specific choice of unit is irrelevant. When the units are not the same, we convert by assuming 40 hours per week and 4.3 weeks per month.
} 
It is important to note that our unemployment insurance variable refers to the amount of U.I. benefits actually received during the unemployment spell and not to the benefits to which the individual was entitled under the law. This difference makes it very difficult to interpret the distinction between those who receive U.I. benefits and those who do not. An individual may not receive U.I. benefits because (I) he is not eligible for benefits (having exhausted benefits or had insufficient previous work experience) or because (2) he has not yet applied for benefits or because (3) he has applied but has not yet received benefits because of administrative delays in the payment of U.I. benefits.

This last point deserves further explanation. In most states there is a one week "waiting period" in the first unemployment spell per benefit year before the individual becomes eligible for unemployment insurance. But even after the individual is eligible for benefits and is actually accruing benefits, he may not be receiving those benefits because of administrative delays in processing payment. A significant fraction of individuals during the first few weeks of unemployment may be accruing benefits even though they have not yet received their first U.I. benefit checks. Such individuals should behave as if the net cost of unemployment is reduced by the accruing U.I. benefits even though they are recorded in our statistics as not receiving benefits. Since about half of the unemployed job losers in May 1976 were in the first 4 weeks of their unemployment spell, this is a potentially serious problem in interpreting the receipt or non-receipt of U.I. benefits.

The problem of interpreting the absence of U.I. benefits does not of course apply to interpreting the ratio of U.I. benefits to wages among those who 
do receive U.I. benefits. Our analysis of the effect of U.I. therefore concentrates on the effect of variations in the $U . I$. replacement rate (i.e., the ratio of U.I. benefits to previous wages) among the U.I. recipients. Some evidence for the entire sample confirms that there are problems of interpreting the nonreceipt of benefits.

\section{Distribution of Reservation Wage Ratios}

As we noted in the introduction, several previous studies have conmented that on average reservation wages are slightly less than some measure of potential wage. These studies have failed, however, to note that significant variation of the reservation wage ratio around its average implies that a substantial fraction of employees have reservation wages that exceed their potential wage. The present study examines the full distribution of reservation wages and shows that about one-third of the unemployed state that their mininum wage requirement exceeds their last wage while less than one-third of the unemployed are willing to accept a wage reduction of 10 percent or more.

The Labor Department's own analysis of the questionnaire elmphasizes the willingness of some of the unemployed to accept low wages but says nothins about the high relative reservation wage required by a substantial group. Thus the Labor Department study notes that "about 1 out of 5 (unemployed) were willing to accept less than $\$ 2.30$ an hour (the minimum wage level in May 1976)" and that "in contrast, only 1 out of 10 of the employed who were paid on an hourly basis reported such low earnings" (Rosenfeld, 1977, p. 39). In the same vein, that study reports that "only 6 percent of the unemployed were asking $\$ 7$ an hour or more, the earnings reported by 11 percent of employed workers" (Rosenfeld, 1977, pp. 39-40). 
In addition to ignoring the high side of the distribution of reservation wages, the Labor Department's comparisons ignore the differences between the potential wages of the unemployed and the actual wages of the employed. Indeed, the Labor Department's report itself cautions that the employed and unemployed have vastly different demographic characteristics and work experience that make their own comparisons potentially very misleading.

Other researchers have sought to reduce this problem of noncornparability by relating each individual's reservation wage to the wage predicted for an employed individual with the same demographic characteristics and labor force experience. ${ }^{1}$ There is, however, strong reason to believe that the unemployed differ from the employed in systematic ways that are not recorded in the survey questionnaire but that influence both the probability of unemployment and the potential wage. Workers of higher "quality" (in a sense that can be observed by employers or prospective employers but that is not recorded in the survey) are more likely to be employed and, if employed, to earn a higher wabe. Comparing the reservation wage of an unemployed worker to the wage predicted from a regression equation estimated with a sample of employed workers is thus likely to understate the ratio of the reservation wage to the true potential wage.

We avoid the "unobserved quality" bias by comparing each individual's reported wage to his own past wage. Even this is subject to problerns. For job losers, our reservation wage ratio is likely to understate the ratio of the reservation wage to the true potential wage for the reasons discussed in

\footnotetext{
${ }^{1}$ See, for example, the studies by Baron and Mellow $(1978,1981)$ and Warner, Poindexter, and Fearn (1980).
} 
section 1. For example, an individual who was overpaid on his previous job, i.e., whose wage exceeded his marginal product, is more likely to have become unemployed. Similarly, individuals are likely to become unemployed when a reduction in the demand for a product causes a fall in the individual's marginal revenue product. In contrast, for individuals who quit their last job, the previous wage may understate the wage that the individual might reasonably hope to receive. An individual may quit because he believes that he is in a job that does not pay him the value of his marginal product or that does not permit him to be as productive as he might be in some other occupation or firw. Our analysis therefore presents separate information for job losers and job leavers.

Although our primary concern is with the distribution of reservation wages and the relative frequency with which reservation wages exceed previous wages, we begin in Table 1 by examining the mean reservation wage ratios for different groups of unemployed workers.

The first line of Table 1 presents the reservation wage ratio for all unemployed individuals in our sample grouped by the number of weeks that they had already been unemployed at the time of the survey. For the sample as a whole, the mean ratio of the reservation wage to the wage on the last job was 1.07, implying that on average the unemployed are seeking a wage that is hisher than the wage that they received on their last job. The reservation wage ratio declines with the duration of the unemployment spell but the differences are not large. ${ }^{l}$ Even among individuals who have been unemployed for six months

\footnotetext{
${ }^{1}$ Several earlier studies found that the reservation wages of individual employees declined with the time that they remained unemployed, e.g., Kasper (1967), Keifer and Neumann (1979), and Holt (1970).
} 
$-13-$

Save for Table 1 
or longer, the mean reservation wage ratio is not significantly different from one. 1,2

Eliminating individuals who voluntarily left their previous job and focusing on job losers shows very similar results (line 2 of Table 1). The overall mean reservation wage ratio for this group is 1.03 and declines slightly from 1.06 among those unemployed less than five weeks to 1.0 at 20 weeks and 0.97 after a year. Lines 3 and 4 divide the job losers into those who are on layof expecting to return to their original job and those who have no expectation of returning. The group on layoff reports a mean reservation wage ratio of approximately 1.0 at all durations while the "other job losers" report reservation wages that on average decline from 1.1 times their past wage during the first four weeks of unemployment to about equal to their last wage after six months and about 10 percent below their last wage after a year. Although the decline of 17 percent in the reservation wage is quite significant, it is even more striking that these job losers began with reservation wages that on average were 10 percent above their last wage and only reached their last wage after six months without work. As expected, the job leavers (line 5) have even higher aspirations which decline only slowly with the length of the spell of unemployment.

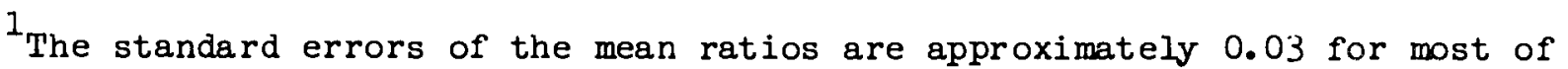
the ratios in Table 1 . Some of the means refer to relatively sinall numbers of individuals (e.g., the mean corresponding to 15 to 19 weeks) and are subject to standard errors that are approximately twice as great.

2 These figures underestimate slightly the extent of the decline in the reservation wage when inflation is raising all wages. In 1970 wages were rising at the rate of about 0.6 percent per month. An individual who is unemployed for five months might ceteris paribus expect a wage that is three percent higher than his last wage. This is offset to the extent that individual skills decay with extended unemployment and that individuals who experience longer periods of unemployment may on average be of lower "quality" relative to their previous wage than individuals who have had only a short spell of unemployment. Adjusting the figures in Table 1 for inflation would imply a stronger negative relation between the reservation wage and unemployment. 
The last three relate the reservation wage to the highest wage that the individual earned on any job after January 1974. For some individuals, the last job was a temporary job with a relatively low wage which provides a poor standard of comparison. For such individuals, the highest wage since January 1974 is a better measure of the potential wage and may even, because of the passage of time, represent an underestimate of the potential wage in 1976. For others, however, the highest earnings in the past two years may represent a temporary job with abnormally high wages that reflect the temporary character of the position.

The mean reservation wage ratios based on the highest previous wage are only a few percent below the reservation wage ratios based on the last job. For all unemployed persons in the sample, the mean is 1.00 in comparison to the 1.07 based on the last wage. For job losers the mean is 0.98 , or five percent below the 1.03 for this group based on the last wage. In short, even when the reservation wage is related to the highest past wage the mean reflects no willingness to reduce wages and implies that there is a significant group that is seeking a higher wage than they have had before.

Table 2 shows the nature of this distribution of relative reservation wages explictly. Among all of the unemployed individuals in our sample (line 1), only 24 percent indicated that they would accept a wage less than 90 percent of their last wage. An additional 11 percent were willing to accept between 90 percent and 100 percent of their previous wage. This is shown as the cumulative 35 percent corresponding to a reservation wage of less than 1.0 . Thus only about one-third of the unemployed were willing to accept any wage reduction at all.

A further 27 percent indicated that they would accept any wage equal to or greater than their last wage but nothing less, thereby bringing the cumula- 
$-16-$

Save for Table 2 
tive percentage of the reservation wage ratio less than or equal to 1 to 62 percent. Thus, 38 percent of the unemployed had a reservation wage greater than their previous earnings. Only about one-fourth of those who required a wage increase said they would accept an increase of less than 10 percent. The cumulative proportion below a reservation wage ratio of 1.1 was thus 0.72 . Fully 28 percent of the unemployed said they would only return to work if they received a wage that was 10 percent higher than their previous wage.

The large percentage of the unemployed who require wage increases to accept new employment is characteristic of both job losers and job leavers. Line 2 shows that only 41 percent of job losers would accept a reduction from their last wage and that 24 percent say they would not accept a job unless it paid at least 10 percent more than their last job. The percentage requiring a wage increase is even higher for job leavers (line 5).

Lines 6 through 8 repeat the analysis with the reservation wage relative to the highest previous wage. Even among the job losers, only 48 percent say they will accept any reduction in pay at all while 20 percent say they require a wage that is at least 10 percent higher than their highest previous wage.

The final three lines restrict the sample to individuals between the ages of 25 and 55. This excludes the young people and those near retirement, two groups that may have weaker labor force attachment and therefore relatively higher reservation wages. But even in this age group, the mean replacement wage ratio is virtually one ( 0.99 for all unemployed and 0.98 for job losers) and less than half of the unemployed indicate a willingness to accept any wage reduction. 
An important reason for the high reservation wage ratios and the high fraction of individuals who require a wage increase as a condition of reemployment is the system of unemployment insurance benefits. Before presenting the evidence for this conclusion in sections 5 and 6 , we turn in the next section to consider the implications of the high reservation wage ratios for the general problem of measuring unemployment.

\section{The Measurement of Unemployment}

The Department of Labor does not consider everyone who is not working to be unemployed. An individual is officially classified as unemployed only if he is available for work and has made specific efforts to find a job within the past four weeks. The purpose of this standard is to count as unemployed only those who really want to work but are unable to find a "suitable" job.

But as we noted in the introduction to this paper, no limit is placed on the individual's reservation wage in defining his willingness to work and therefore his unemployment status. No matter how high or infeasible the individual's reservation wage may be, he is classified as unemployed if within four weeks he did anything to find employment, including asking friends or relatives about jobs, checking with a private or public agency or answering newspaper ads.

It is interesting to consider what happens to the measured unemployment rate if we exclude individuals with "unreasonably" high reservation wages. In May 1976, the overall unemployment rate was 6.7 percent. Individuals classified as job losers and job leavers accounted for 4.2 percentage points or a little less than two-thirds of total unemployment. In the sample that we analyzed in the previous section, only 35 percent of job losers and leavers indi- 
cated a willingness to work for less than their last pay. If we defined an individual as unemployed only if he is willing to accept a wage that is lower than his last wage, 59 percent of those who are currently classified as unemployed job losers and 68 percent of job leavers would be reclassified and no longer counted as unemployed. The 4.2 percent of the labor force that is classified as unemployed job losers and leavers would be reduced to 1.6 percent and the overall unemployment rate would fall from 6.7 percent to 4.1 percent. This sharp reduction in the defined rate of unemployment occurs without any reexamination of the reservation wages of those who are classified as new entrants or reentrants.

A weaker standard of reclassification continues to regard as unemployed anyone whose reservation wage does not actually exceed his past wage even though he is not willing to reduce his wage at all. Among job losers, 31 percent would be reclassified by this standard because their reservation wage ratio exceeded their last wage; among job leavers, 42 percent would be reclassified. The result would be a 1.4 percentage point reduction in the unemployment rate to 5.3 percent. Again, this 20 percent reduction in the unemployment rate occurs without any reclassification of the new entrants and reentrants.

An even weaker standard accepts as unemployed anyone whose reservation wage does not exceed 110 percent of his last wage. Even this very weak standard eliminates more than one-fourth of job losers and leavers and therefore reduces the unemployment rate to 5.6 percent.

Table 3 presents the official May 1976 unemployment rates for the population as a whole and for several demographic groups and compares these official rates with two alternative "adjusted" unemployment rates. I'he "adjusted rate $1 "$ figures exclude from the unemployed that share of the 
$-20-$

Save for Table 3 
losers and leavers who reported reservation wages 1.10 or more times their last wage. The "adjusted rate 2 " figures exclude that share of the losers and leavers whose reservation wage ratio exceeds 1.0 . No figures are presented for the more stringent criterion that classifies an individual as unemployed only if he is willing to accept less than his previous wage.

The adjusted rate 2 figures indicate, as we noted in the previous paragraph, that reclassifying anyone who wants a wage increase in his previous wage reduces measured unemployment by more than one-fifth. The most striking difference among the subgroups is the small effect of reclassification on teenagers. Since teenage unemployment includes many more new entrants and reentrants, reclassification on the basis of previous wages is quite limited.

5. The Reservation Wage Equation: Specification and Previous Research

We turn now to examine the extent to which the level of unemployment insurance benefits raises the level of reservation wages and the probability that the individual's reservation wage ratio will exceed one. In the theory of search unemployment, the individual's reservation wage is a decreasing function of the cost of remaining unemployed and therefore an increasing function of the ratio of unemployment benefits to previous wages. 1

Although unemployment benefit rules differ among states, the typical benefit formula provides that an unemployed worker gets basic weekly benefits equal to about half of his previous gross weekly earnings, subject to a maximum

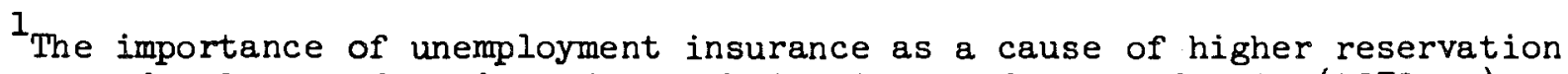
wages and a longer duration of search is discussed in Feldstein $(1973 \mathrm{a}, \mathrm{b})$ and developed in formal models by Baily (1977, 1978), Mortenson (1977) and Burdett (1979).
} 
weekly amount that is a binding constraint for a minority of beneficiaries. In addition, about one-third of the labor force lives in states that provide additional benefits for dependents. Unemployment benefits are subject to federal income tax only when family income exceeds $\$ 25,000$ for a couple filing a joint return or $\$ 20,000$ for a single person filing an individual return; even in these households, half of unemployment benefits are excluded in calculating taxable income. ${ }^{1}$ Unemployment benefits are also not subject to payroll tax or to state income tax. ${ }^{2}$ Unemployment benefits therefore typically replace about two-thirds of recipients' lost net income. ${ }^{3}$

Earlier studies, although not dealing directly with the reservation wage ratio, indicate that higher levels of unemployment insurance benefits do increase reservation wages. Warner, Poindexter and Fearn (1980) use the 1970 Census Employment Survey and relate the job-seekers reported reservation wage to the market wage predicted for someone with those demographic characteristics and to a dummy variable that indicates whether the individual receives unemployment insurance benefits. The receipt of unemployment benefits raises the reservation wage by 8.6 percent (with a standard error of 4.0 percent.) There is no information on the amount of benefits or on the ratio of the reservation wage to the individual's previous wage.

Fishe (1982) studies a group of job seekers in Florida for whom data are available on individual attributes and on the market wage of the job that

${ }^{1}$ No federal tax was levied on unemployment insurance in 1976.

${ }^{2}$ Some states levy a tax on the federal income tax base or a tax that is proportional to the federal tax payments. In either of these cases, unemployment benefits are subject to partial taxation at the state level.

${ }^{3}$ See Feldstein (1974) for a detailed analysis of unemployment insurance replacement rates. 
the individual takes at the end of the unemployment spell. Although there is no reported information on reservation wages, Fishe uses a censored regression model to obtain maximum likelihood estimates of a reservation wage equation. He concludes that unemployment insurance raises the reservation wage and that the reservation wage varies inversely with the remaining length of the period for which benefits will still be paid.

The final study of unemployment insurance and reservation wares of which we are aware is the research by Pucher and Harrison (1975) who report regression equations based on the 1970 Census Employment Survey. They focus on inner city workers and relate the observed reservation wage to a predicted potential wage (based on the job seeker's demographic characteristics) and dummy variables indicating whether the individual received a small or large amount of unemployment insurance benefits in the previous year. Since these unemployment insurance variables reflect the duration of unemployment but refer to a different period, it is difficult to know how their positive coefficients should be interpreted.

In short, while the previous studies suggest that unemployment insurance raises reservation wages, none of these studies actually uses data on either the ratio of unemployment benefits to wayes or on the ratio of the reservation wage to the individual's previous wage. The present study therefore ains at a more explicit evaluation of the effect of unemployment insurance by relating the reservation wage ratio to the unemployment insurance replacement rate. We also give particular attention to the effect of unemployment insurance on the probability that an individual's reservation wage will exceed the wage (or 1.1 times the wage) that he earned on his last job. 
Our unemployment insurance variable is the ratio of the weekly benefits received by the individual during the current spell of unemployment to the net wage that he earned on his last job. It would in principle be desirable to calculate the marginal income tax rate for each person in our sample and to use that tax rate to calculate the ratio of $U . I$. benefits to previous net earnings. Because the data required to calculate each individual's marginal tax rate are not available for our sample, we have assumed a common marginal tax rate of 30 percent. Because we do not recognize differences in marginal tax rates, our measure of the U.I. replacement ratio understates the replacement ratio for individuals with high marginal tax rates and overstates the replacement ratio for individuals with low marginal tax rates. Since individuals with high marginal tax rates are likely to be individuals with high wage rates and therefore lower than average U.I. replacement ratios, ${ }^{\perp}$ our procedure generally understates the low replacement rates and overstates the high replacement rates.

An example will illustrate the nature of this bias. Consider a low wage individual who earns $\$ 200$ a week, receives benefits of $\$ 100$ a week and pays a marginal tax rate of 25 percent. We measure his replacement rate as $\$ 100$ divided by 70 percent of $\$ 200$ or 0.71 ; in reality his replacement rate is $\$ 100$ divided by 75 percent of $\$ 200$ or 0.67 . A high wage individual earns $\$ 400$ a week, receives benefits of $\$ 150$ a week and pays a marginal tax rate of 35 percent. We measure his replacement rate as $\$ 150$ divided by $\$ 280$ or 0.54 when the correct measure is 0.58 . Thus our replacement rates stand in the ratio of 0.71 to 0.54 or 1.31 while the "true" replacement rates stand in the ratio of 0.67

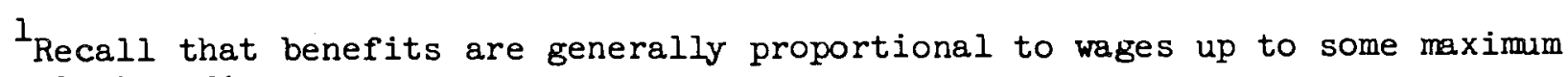
weekly benefit. 
to 0.58 or 1.16 .

The result of exaggerating the variation in the measured U.I. replacement rate while keeping the mean unchanged is to bias its estimated coefficient in a regression equation toward zero. I In addition, any purely randorn errors in the U.I. replacement rate introduced by our procedure will cause a further downward bias of the usual errors in variables type. For both reasons, therefore, our procedure is likely to underestimate the effect of any changes in unemployment benefits.

We have already described the measurement of the dependent variable of our analysis, the reservation wage ratio. We use the ratio of the individual's stated reservation wage to the wage that he earned on his last job. The other variables in our reservation wage equation are of two kinds: (1) measures of other income during unemployment that might raise the reservation wage and (2) demographic variables that might influence the reservation wage directly and that are included in the equation as a precaution.

The survey provides information on total nonwage income during the previous month, an amount that includes not only a small amount of interest and dividends but also the value of unemployment benefits, welfare, disability payments, food stamps, etc. We subtract from this an estimate of the unemployment benefits received during that month and divide the differences by the wage on the last job. We refer to this as the Nonwage Income Ratio and expect that it will increase the individual's reservation wage ratio.

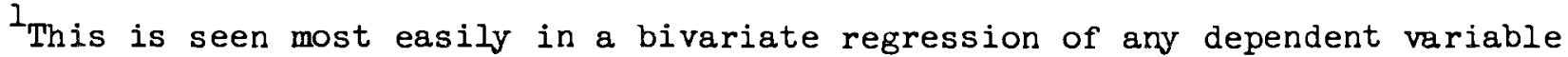
on the U.I. replacement rate. The regression coefficient is the ratio of the covariance between the variables to the variance of the U.I. replacement rate. Increasing the variance of the replacement rate by a factor of $\lambda$ increases the covariance by $\sqrt{\lambda}$ and therefore reduces the regression coefficient to $1 / \sqrt{\lambda}$ times its true value.
} 
Since data are not available on the amount of supplementary unemployment benefits, welfare, and other forms of nonwage income, it is not possible to measure their specific effects on reservation wages. Information is available, however, on whether or not the individual received welfare payments or supplementary unemployment benefits. We include binary variables for these two income sources (which take the value of 1 if that type of income is received and zero otherwise) and regard their coefficients as a weak indication of whether each type of income affects the reservation wage ratio in a different way from other forms of nonwage income. In virtually every equation, the coefficients of these variables are negligible, suggesting that the distinction among these income sources does not matter. We would emphasize, however, that this is a very weak test of whether different types of income have different effects on reservation wage ratios.

The survey also provides information on whether another worker is present in the household. The presence of such a worker provides additional income which makes finding a job less urgent than it would otherwise be. Such income is, however, very different from unermloyment insurance or other employmentconditioned transfers; an additional worker in the household has an income effect but does not change the cost of unemployment and therefore has no substitution effect. We would expect the effect of this variable to be positive but small and that is generally what we find. ${ }^{l}$

Closely related to the possibility of additional family income is the extent of the individual's family responsibility. We add a binary variable that is equal to one if the individual is a married man. Since we are controlling for the presence of an additional worker, the coefficient of the married man

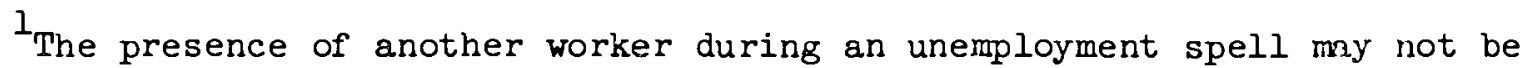
exogenous but a response to the unemployment.
} 
variable represents a negative income effect and should be expected to reduce the reservation wage if it has any noticeable effect at all.

Four other demographic variables are included in the equation without any clear a priori expectation about the likely direction of their effect on the reservation wage ratio. They are included because of the possibility that they might have an effect and might be correlated with the unemployment insurance replacement ratio. These variables are the individual's age in years, the race of the individual (a binary variable equal to one if the individual is white), the sex of the individual (a binary variable equal to one for males) and the number of years of schooling that the individual has had. 1

6. Estimated Effects of Unemployment Insurance on the Reservation Wage Ratio Table 4 presents estimated coefficients for the specification discussed in the last section. Separate equations are estimated for individuals classified as "job losers on layoff", "other job losers," and "job leavers." Only individuals who received unemployment insurance are included in the sample because of the difficulties and ambiguities associated with the non-receipt of benefits. ${ }^{2}$

The coefficient of the unemployment compensation variable is positive and significantly different from zero in all three equations, implying that a higher unemployment insurance replacement rate raises the reservation wage

${ }^{1}$ We have also included the level of the individual's previous wage. The coefficient of this variable is generally insignificant and its presence does not alter the estimated effect of the $U$. I. replacement rate.

${ }^{2}$ When the sample is expanded to include nonrecipients of unemployment compensation, the coefficient of the unemployment insurance variable is generally not significantly different from zero. See section 2 for a discussion of the difficulties of interpreting the absence of benefits. The exclusion of nonrecipients is the primary reason why the regression sample is 642 instead of the 2228 observations in the tables. 
$-28-$

Save for Table 4 
ratio. The coefficient of 0.129 for job losers on layoff implies that increasing the unemployment insurance replacement rate from 0.4 to 0.7 raises the reservation wage ratio by 4 percentage points for someone in this group. The effect is substantially larger for job losers who are not on layoff; an increase in the U.I. replacement rate from 0.4 to 0.7 raises their reservation wage by more than 12 percentage points. Before discussing the implication of these figures for the duration of unemployment or the effect of unemployment insurance on the probability that the reservation wage ratio exceeds 1.0 or 1.1 , we comment briefly on the other coefficients in Table 4.

A greater amount of nonwage income relative to the individual's last wage raises the reservation wage ratio for both groups of job losers but not for job leavers. Since only some of this nonwage income is conditional on continued unemployment, the effect is substantially smaller than that of the unemployment insurance benefits.

The coefficients of the dummy variables for the receipt of welfare and of supplementary unemployment insurance are generally insignificant, indicating that these forms of nonwage income did not affect reservation wages differently than other forms of nonwage income (except unemployment insurance). The exception is for the group of job losers who are not on layoff. In this group, the receipt of welfare and supplementary benefits appears to raise reservation wages more than other forms of nonwage income.

The presence of a second worker in the household has only an income effect and therefore is expected to have a weaker impact on the reservation wage ratio than unemployment insurance. Although the coefficient is positive in two of the three equations, it is never statistically significant. This and the evidence on nonwage income both indicate that unemployment insurance is impor- 
tant because it affects the cost of continued unemployment (a substitution effect) and not just because it increases the individual's financial resources.

The dumny variable for married men reinforces this conclusion. The negative coefficient reflects the adverse "income effect" of additional spending responsibilities but the small size and lack of statistical significance reflects the unimportance of income effects relative to substitution effects. None of the four demographic variables had a statistically significant coefficient. Equations were also estimated with more detailed denographic specification (e.g., a set of binary variables for age) but these specifications did not add significantly to the explanatory power of the equation or chane the coefficient of the unemployment insurance variable to any appreciable extent. In the next section we show that the duration of unemployment is likely to increase in a very nonlinear way with the reservation wage ratio. Increasing the reservation wage ratio from 0.8 to 0.9 has a much smaller effect on the duration of unemployment than increasing the reservation wage ratio from 1.0 to 1.1 . Since the median reservation wage ratio is 1.0 , the estimated effect of unemployment insurance presented in Table 4 implies that the changes in the reservation wage caused by unemployment insurance can have a very substantial effect on the probability that the reservation wage exceeds 1.0 or 1.1 and therefore on the likely duration of unemployment.

The specification of the equation in Table 4 assumes a linear relationship between the unemployment insurance ratio and the reservation wase ratio. We have also included a quadratic term in the U.I. ratio but found that its coeficient is not significantly different from zero. The coefficient of the quadratic term is however generally positive, suggesting that high U.I. 
ratios have a disproportionately large effect on the reservation wage ratio.

As a further check on the effect of unemployment insurance on the likelihood of high reservation wage ratios, we have used the specification of Table 4 to study directly the probability that an individual's reservation wage ratio exceeds 1.0 or 1.1 . The dependent variables in the "greater than 1.0 " regressions is one if the individual's reservation wage ratio exceeds 1.0 and zero otherwise. Table 5 summarizes the effect of the unemployment insurance ratio on these reservation wage probabilities for the three unemployment groups. Only the coefficient of the U.I. ratio variable is presented although each coefficient is taken from a full specification like those of Table 4. The other coefficients are qualitatively very similar to those of Table 4, indicating weak income effects and virtually no differences among demographic groups. The mean of the dependent variable and the $R^{2}$ value for the equation as a whole are also presented.

In each case, the coefficient of the unemployment insurance variable is large and statistically significant, indicating a substantial effect of unemployment insurance on the probability that the unemployed individual will have a high reservation wage. Consider, for example, the group of job losers on layoff. The average ratio of unemployment insurance benefits to the previous net wage for this group is 0.66 and 31 percent of the group have reservation wages above the wage on their last job. Reducing all unemployment insurance ratios in this group by $0.2^{l}$ would reduce the 31 percent with high reservation wages to 23 percent. Completely eliminating the unemployment insurance reduces the mean probability of a reservation wage greater than 1 by $0.40(0.66)=0.264$ to 0.046 .

$I_{\text {This }}$ reduction is approximately equivalent to taxing unermloyment benefits. 


$$
-32-
$$

Save for Table 5 . 
7. Unemployment Insurance, Reservation Wages and the Duration of Unemployment

By raising the reservation wage, high unemployment insurance benefits increase the expected duration of unemployment. Because the relationship between the reservation wage and the expected duration of unemployment is very nonlinear, the effect of unemployment insurance is particularly important when it raises the reservation wage above the wage that the individual earned on his previous job. ${ }^{1}$

Although we lack sufficient information to do a complete analysis of the effect of unemployment insurance on expected durations of unemployment, it is useful to examine the implications of a simple model that illustrates the nonlinear character of the effect of unemployment insurance and of reservation wage ratios.

Assume that each individual who becomes unemployed adopts a reservation wage $(R)$ that reflects his unemployment benefits, his previous wage $\left(w_{0}\right)$ and other factors that influence his expectations about the distribution of potential wage offers $[f(w)]$. Assume further that the individual then receives wage offers $(w)$ that represent random drawings from this distribution of potential wage offers and accepts the first offer that exceeds his reservation wage. The model simplifies reality by assuming that the individual does

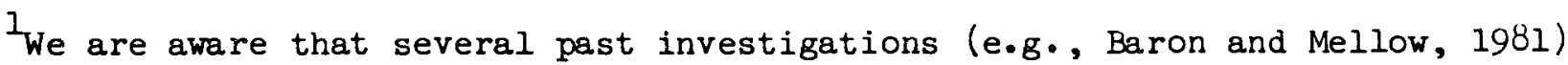
have failed to find a significant relationship between reported reservation wages and subsequent labor market experience. The theoretical relationship is unambiguous and several explanations may be proposed for the lack of an observed relationship. For example, other job attributes may induce workers to settle for wages below their stated reservation wage. Alternatively, workers may revise their reservation wages in response to information obtained while unemployed.
} 
not revise his reservation wage over time ${ }^{l}$ and that wage offers arrive in random order. ${ }^{2}$

In such a model, the probability $(P)$ that the individual accepts each wage offer is equal to the probability that the offer exceeds his reservation wage:

$$
P=\int_{R}^{\infty} f(w) d w .
$$

If wage offers are received every $t$ days, the expected duration of unemployment (E) is $E=t / P$. For the normal distribution, or for any distribution in which the "tails" have less density per unit of w than the center of the distribution, $P$ will vary with $R$ in a very nonlinear way. The higher the value of $R$, the greater the proportional change in $P$ per unit change in $R .^{3}$ Since the expected duration of unemployment is inversely proportional to the acceptance probability, the sensitivity of the expected duration of unemployment to the value of $R$ is an increasing function of $R$.

This idea can be illustrated by assuming that the distribution of potential wage offers is normal. The further assurnption that the mean of the potential wage offers for an unemployed individual is the wage on his last job is a conservative one since the true mean is probably lower (for the reasons discussed in section 1 ) and the assurnption of a higher mean increases the pro-

${ }^{l}$ An individual who is unsure about the parameters of $f(w)$ will use his wage offers to revise his subjective estinates of these parameters and will alter his reservation wage as his estimates of these parameters change.

2 This precludes a search strategy in which the individual ranks firms by the expected prevailing wage and applies for employment in decreasing order of this potential wage.

3 This property holds for a much wider class of distributions. Even if the probability $P$ varies linearly with $R$ (as it would for a uniform distribution), the expected deviation varies inversely with $P$ and is therefore a nonlinear function of $R$. 
bability of acceptance for every reservation wage level and thus reduces the sensitivity of the expected duration to unemployment insurance. Since the standard deviation of the potential wage offer distribution is not known, we will present estimates conditional on a variety of plausible values.

Before looking at these estimates, it is useful to examine one example in detail. Consider an individual who is an unemployed job loser who is not on layoff, who receives U.I. benefits that replace 70 percent of his previous net wage, and whose reservation wage is 1.1 times the wage on his last job. Assume that the mean of his potential wage offer distribution is the wage on his last job and the standard deviation of that distribution is 10 percent of the mean. Thus the individual's probability of receiving a wage offer as high as his reservation wage is equal to the probability of exceeding the mean of the offer distribution by one standard deviation and is thus $1-F(1.0)=0.16$ when $F(\cdot)$ is the cumalative normal distribution with mean zero and standard deviation 1. The reservation wage ratio equation for "other job losers" presented in Table 4 implies that each additional 10 percentage points of the U.I. replacement ratio raises the reservation wage ratio by 4.2 percentage points. Thus lowering the individual's U.I. replacement ratio from 0.7 to 0.5 would reduce his reservation wage ratio from 1.10 to 1.02 . The probability of receiving an acceptable wage would rise to $1-F(0.2)=0.42$. The expected duration would fall from $t / 0.16$ to $t / 0.42$ or to 38 percent of its previous value. This figure is shown in Table 6 in the row corresponding to an initial reservation wage ratio of 1.1 (the second row) and in the column corresponding to the standard deviation equal to 10 percent of the mean and the reduction in the U.I. ratio from 0.7 to $0.5($ column 7$)$.

More generally, Table 6 shows the effect of reducing the U.I. replacement ratio on the probability of receiving an acceptable wage of fer and on the 
$-36-$

Save for Table 6 
expected duration of unemployment. The figures refer to "job losers not on layof $f^{\prime \prime}$ and use the U.I. ratio coefficient of 0.416 presented in Table 4 for this group. Although similar calculations could be done for workers on layoff and for job leavers, the principal effect of U.I. on job search relates to job losers who are not on layof

The first column shows the initial reservation wage ratio. The next three columns show the acceptance probabilities corresponding to those reservation wage ratios if the standard deviation of wage offers is 5 percent of the mean value (column 2), 10 percent (column 3) and 15 percent (column 4). The next group of columns correspond to the effect of reducing the unemployment insurance ratio from 0.7 to 0.5 . The first of these columns shows the new reservation wage ratio predicted to result from the reduced unemployment insurance ratio. For each alternative standard deviation, the next 3 columns then show the new relative duration of unemployment, i.e., the ratio of the expected duration with a U.I. replacement ratio of 0.5 to the expected duration with a U.I. ratio of 0.7 . The final four columns then repeat the analysis for a reduction in the U.I. ratio from 0.7 to 0.3 .

The figures in columns 6,7 and 8 show that reducing the U.I. ratio from 0.7 to 0.5 has a very substantial effect on the expected duration of unemployment for those individuals whose reservation wage would otherwise equal or exceed their previous wage. Even someone whose reservation wage ratio is reduced from 1.0 to 0.92 will experience a 37 percent decrease in expected unemployment time if the standard deviation is equal to ten percent of the mean wage offer.

Doubling the decrease in the U.I. ratio (i.e., decreasing it from 0.7 to 0.3 instead of from 0.7 to 0.5 ) has a less than proportional effect on the expected duration. For example, with a starting reservation wage ratio of 1.1 
and a standard deviation of 0.15 , the probability of an acceptable wage offer is 0.25 and therefore the expected duration of unemployment is 4.0 times the interval between wage offers. Reducing the U.I. replacement rate from 0.7 to 0.5 lowers the reservation wage ratio to 1.02 and increases the probability of an acceptable wage offer to 0.45 . This reduces the expected duration of unemployment to 2.2 times the wage offer interval, or 56 percent of its previous value. A further reduction in the U.I. ratio to 0.3 lowers the reservation wage ratio to 0.93 and thus increases the probability of an acceptable wage of fer to 0.68. The expected duration of unemployment falls to 1.5 times the wage offer interval or 37 percent of its initial value. Thus the first 20 percentage point reduction in the U.I. replacement ratio implied a 44 percent reduction in the expected duration while the additional 20 percentage point reduction in the U.I. ratio reduced expected duration by only 19 percent of its original value. ${ }^{1}$

In addition to this analysis of the expected duration of unemployment, it is particularly interesting to examine the effect of unemployment insurance on the probability of long durations of unemployment. Consider an individual who, with a U.I. replacement ratio of 0.7 , has a reservation wage that is 1.1 times his previous wage. Table 6 shows that if the standard deviation of wage offers is 10 percent of his previous wage, the probability that each wage offer is acceptable is 0.1587 . Although the expected duration of unemployment is 6.3 times the interval between wage offers, the probability that the individual will

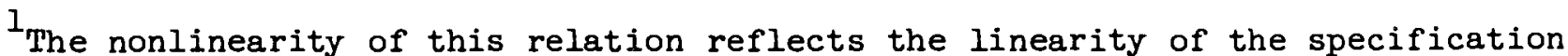
in Table 4. If the sensitivity of the reservation wage to the unemployment insurance ratio were a rapidly decreasing function of the U.I. ratio, the reductions in low U.I. rates could have a more powerful effect. Estimates of the nonlinear generalization of the equations in Table 4 indicate that nonlinear specifications are not statistically better and that the direction of nonlinearity actually reinforces the conclusion in the text by showing that the sensitivity of the reservation wage is greater at higher levels of the U.I. ratio.
} 
itself 1.0 , even small changes in the reservation wage can have a substantial impact on unemployment.

The analysis of section 6 shows that the level of unemployment benefits relative to previous wages has a powerful effect on the individual's reservation wage. A 10 percent increase in the U.I. replacement ratio increases the reservation wage by about 4 percent for job losers who are not on layof $f$ and by somewhat less for other unemployed groups. Separate regressions to analyze the high reservation wage per se show that a 10 percent increase in the U.I. replacement ratio also increases by about four percentage points the probability that an unemployed individual will require a wage increase of 10 percent or more.

The estimates that we have presented imply that reducing unemployment insurance benefits could significantly lower the average duration of unemployment and the relative number of long-duration spells of unemployment. Because of the nonlinear response of the unemployment duration to the reservation wage, reducing a high unemployment insurance ratio by 10 percentage points is likely to have a greater impact on unemployment than reducing a low unemployment insurance ratio by 10 percentage points.

Taxing unemployment benefits in the same way that earnings are taxed would reduce net unemployment insurance by about 30 percent although the reduction would be mach smaller for individuals with low overall annual income. The typical U.I. ratio would decline from about 0.7 to 0.5 . Since such a reduction in the $U . I$. ratio implies a reduction in the reservation wage ratio of more than 10 percentage points, the implied impact on total unemployment and on relatively long durations of unemployment would be very substantial.

The May 1976 survey is currently a unique source of data on reservation wages and unemployment insurance. It would obviously be valuable to have 
a replication of that survey under different economic conditions. In such a replication, it would be useful to collect more information on the individuals who do not receive unemployment insurance and the reasons why they do not. With the existing data, a possible next step would be an analysis that explicitly links the observed durations of unemployment to the reservation wage in the framework of a model with time-varying reservation wages.

The optimal level of unemployment benefits for job seekers depends on a balance between protection and distortion: protection against the discomfort of reduced consumption during unemployment and distortion of the duration of unemployment. The research presented in this paper suggests that a constant level of unemployment benefits for an individual may not be optimal. Instead, benefits might be varied over time to offset the effect of excessive reservation wages. In particular, it is possible to learn something about the individual's unobserved reservation wage by the amount of time that he has remained unemployed. A long-spell of unemployment reflects combinations of a high reservation wage and/or a string of unlucky wage offers. More formally, the likelihood function of the individual's reservation wage can be inferred from the observed duration of unemployment if the distribution of wage offers is known. This suggests that the optimal U.I. benefit might, ceteris paribus, be a decreasing function of the duration of the unemployment spell. The formal solution to this problem remains to be investigated. 1

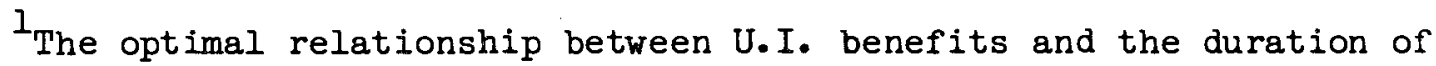
unemployment should also reflect the fact that longer spells impose a greater financial hardship. A "deductible" in the form of a waiting period or a continuously varying replacement ratio may therefore be optimal.
} 


\section{Bibliography}

Baily, M. (1977) "Unemployment Insurance as Insurance for Workers"

Industrial and Labor Relations Review, 495-504.

Baily, M. (1978) "Some Aspects of Optimal Unemployment Insurance" Journal of Public Economics 10, 379-402.

Baron J. and Mellow, W. (1981) "Changes in Labor Force Status Among the Unemployed" The Journal of Human Resources XVI, 3, 427-441.

Feldstein, M. (1973a) Lowering the Permanent Rate of Unemployment, A study

Prepared for the use of the Joint Economic Committee, Congress of the United States, Washington: U.S. Government Printing Office. (1973b) "The Economics of the New Unemployment" The Public

Interest $33,3-42$.

(1974) "Unemployment Compensation: Adverse Incentives and

Distributional Anomalies" National Tax Journal 27, 2, 231-44.

(1975) "The Importance of Temporary Layoffs: An Empirical

Analysis" Brookings Papers on Economic Activity 3, 725-44.

(1976) "Temporary Layoffs in the Theory of Unemployment" Journal

of Political Economy 84, 5, 937-57.

(1978) "The Effect of Unemployment Insurance on Temporary Layoff

Unemployment" American Economic Review, 191-222.

Fishe, R. (1982) "Unemployment Insurance and the Reservation Wage of the

Unemployed" The Review of Economics and Statistics LXIV, 1, 12-17.

Hall, R. and E. Lazear (1982) "The Excess Sensitivity of Layoffs and Quits to Demand" NBER Working Paper No. 864, Cambridge, MA. 
Holt, C.C. (1970) "Money Wage Dynamics and Labor Market Equilibrium" in E.

Phelps (ed.) Microeconomic Foundations of Employment and Inflation

Theory, New York: Norton.

Kasper, H. (1967) "The Asking Prince of Labor and the Duration of Unemployment" The Review of Economics and Statistics 49 165-72.

Kiefer, N.M. and G. Neumann (1979) "An Empirical Job Search Model, with a

Test of the Constant-Reservation-Wage Hypothesis" Journal of Political

Economy 87, 89-107.

Lazear, E. P. (1981) "Severance Pay, Pensions and Efficient Mobility"

National Bureau of Economic Research Working Paper No. 854, Cambridge,

MA.

Lazear, E. P. (1982) "Pensions as Severance Pay" in Z. Bodie and J. Shoven, (eds.), Financial Aspects of the U.S. Pension System, an NBER project report, University of Chicago Press, forthcoming.

McCall, J.J. (1970) "Economics of Information and Job Search" Quarterly Journal of Economics 84, 113-126.

Medoff, J.L. and K.G. Abraham (1978) "Experience, Performance, and Harnings" NBER Working Paper No. 278, Cambridge, MA.

Mortenson, D. (1977) "Unemployment Insurance and Job Decisions" Industrial and Labor Relations Review XXX, 505-517,

Pucher, J. and Bennett Harrison (1975) "Reservation Wages, Unemployment, and Earnings Expectations in Urban Labor Markets", New York: Research Center for Economic Planning.

Rosenfeld, C. (1977) "Job Search of the Unemployed, May 1976" Monthly Labor Review, U.S. Department of Labor, Special Labor Force Report 210, 39-43. 
Stigler, G. (1962) "Information in the Labor Market" Journal of Political Economics LXX, 94-105.

Warner J.T., C. Poindexter, Jr., and R. M. Fearn (1980) "Employer-Employee Interactions and the Duration of Unemployment" The Quarterly Journal of Economics XCIV, 2, 211-233. 


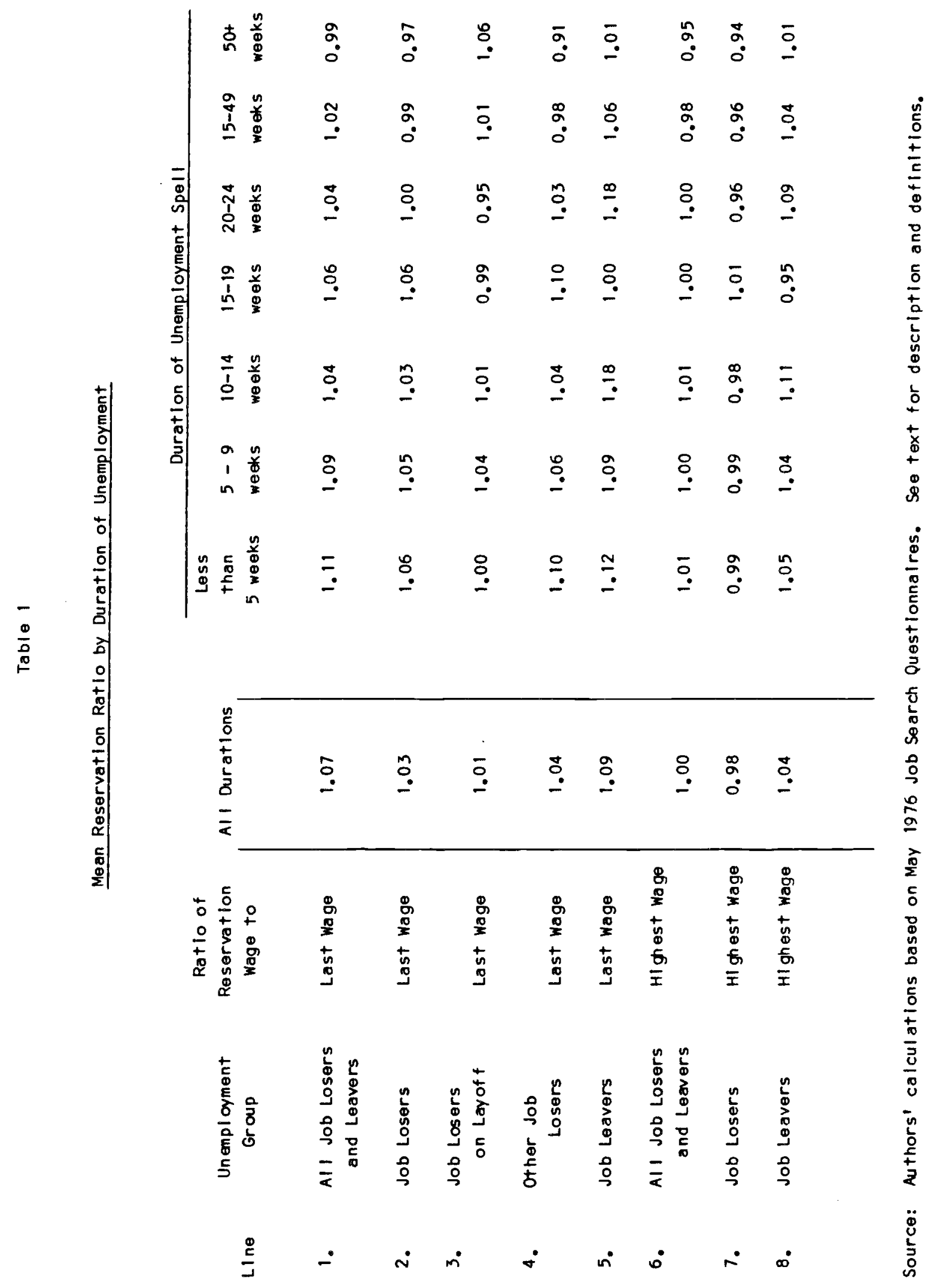


Table 2

Cumulative DIstribution of Reservation Wage Ratios

\begin{tabular}{|c|c|c|c|c|c|c|c|}
\hline \multirow{4}{*}{$\operatorname{LIn} \theta$} & \multirow{4}{*}{$\begin{array}{l}\text { Unemp loyment } \\
\text { Group }\end{array}$} & \multirow{4}{*}{$\begin{array}{l}\text { Ratlo of } \\
\text { Reservation } \\
\text { Wage to }\end{array}$} & \multirow{4}{*}{ Mean } & \multirow{3}{*}{$\begin{array}{l}\text { Less } \\
\text { than }\end{array}$} & \multicolumn{2}{|c|}{ ProportIon with Ratlo } & \multirow{2}{*}{ Less } \\
\hline & & & & & Less & Less than & \\
\hline & & & & & than & or equal to & than \\
\hline & & & & 0.9 & 1.0 & 1.0 & 1.1 \\
\hline \multirow{2}{*}{1.} & Al I Unemp loyed & & & & & & \\
\hline & $\begin{array}{c}\text { (job losers and } \\
\text { leavers) }\end{array}$ & Last Wage & 1.07 & 0.24 & 0.35 & 0.62 & 0.72 \\
\hline 2. & Job Losers & Last Wage & 1.03 & 0.29 & 0.41 & 0.69 & 0.76 \\
\hline \multirow[t]{2}{*}{3.} & Job Losers & & & & & & \\
\hline & on layot $f$ & Lost Wage & 1.01 & 0.25 & 0.38 & 0.71 & 0.80 \\
\hline \multirow[t]{2}{*}{ 4. } & Other Job & & & & & & \\
\hline & Losers & Lost Wage & 1.04 & 0.31 & 0.43 & 0.68 & 0.74 \\
\hline 5. & Job Leavers & Last Wage & 1.09 & 0.22 & 0.32 & 0.58 & 0.69 \\
\hline 6. & Al I Unemployed & HI ghest Wage & 1.00 & 0.34 & 0.46 & 0.71 & 0.79 \\
\hline 7. & Job Losers & HIghest Wage & 0.98 & 0.36 & 0.48 & 0.73 & 0.80 \\
\hline 8. & Job Leavers & HI ghest Wage & 1.04 & 0.28 & 0.39 & 0.65 & 0.76 \\
\hline \multirow[t]{2}{*}{9.} & Al I Unemp loyed & & & & & & \\
\hline & age $25-55$ & Last Wage & 0.99 & 0.34 & 0.47 & 0.75 & 0.81 \\
\hline \multirow[t]{2}{*}{10.} & Job Losers & & & & & & \\
\hline & age $25-55$ & Last Wage & 0.98 & 0.35 & 0.47 & 0.74 & 0.82 \\
\hline \multirow[t]{2}{*}{11.} & Job Leavers & & & & & & \\
\hline & age 25-55 & Last Wage & 1.02 & 0.31 & 0.44 & 0.73 & 0.81 \\
\hline
\end{tabular}

Source: Authors' calculations based on May 1976 Job Search Questlonnalre. See text for description and definitions. 
Table 3

Unemployment Rates Adjusted for High Reservation Rates

\begin{tabular}{|c|c|c|c|c|}
\hline \multirow[b]{2}{*}{ Group } & \multirow[b]{2}{*}{$\begin{array}{l}\text { Reported May } 1976 \\
\text { Unemployment Rate }\end{array}$} & & Exclude & Exclude \\
\hline & & $\begin{array}{c}\text { Share of Unemp loyment } \\
\text { Accounted for By } \\
\text { Losers and Leavers }\end{array}$ & $\begin{array}{l}\text { Rw }>1.1 \text { wo } \\
\text { Adjusted } \\
\text { Rate } 1^{*}\end{array}$ & $\begin{array}{l}\text { Rw }>\text { wo } \\
\text { Ad Justed } \\
\text { Rate 2* }\end{array}$ \\
\hline Total & 6.7 & 62.7 & 5.6 & 5.3 \\
\hline Males, age 20+ & 5.3 & 79.2 & 4.3 & 4.0 \\
\hline Females, age $20+$ & 6.4 & 62.5 & 5.4 & 5.0 \\
\hline $16-19$ year olds & 16.8 & 31.0 & 15.7 & 15.2 \\
\hline Whites & 6.1 & 63.9 & 5.1 & 4.8 \\
\hline Nonwhites & 11.4 & 55.3 & 8.7 & 8.2 \\
\hline
\end{tabular}

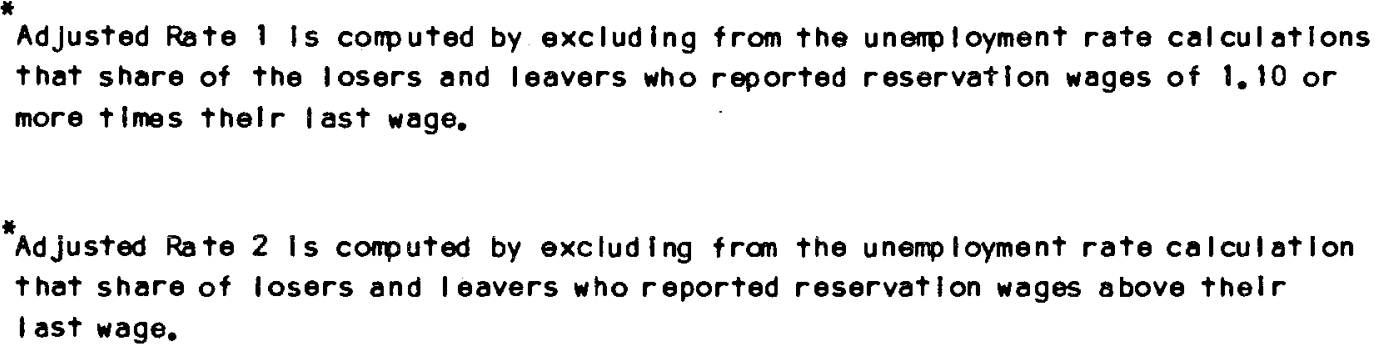

Source: Unemployment dato from Employment and Earnings, June 1976, Table A-12. Adjustments based on author's calculations using Job Search Questionnaire Data. 
Table 4

Ef fects of Unemployment Insurance and other Varlables on Reservation Wage Ratlos

Varlable

U. I. Replacement

Ratio

Nonwage Income

Ratio

Wel fare

Supplementary

Unemp loyment

Benefits

Other Worker

Present

Marrled Man

Age

White

Male

Education

Constant

$R^{2}$

N

Mean of

Dependent Varlable
Unemployment Group

Job Losers Other Job Job Leavers
on Layoff

Losers

$\begin{array}{ccc}0.129 & 0.417 & 0.294 \\ (0.057) & (0.070) & (0.184)\end{array}$

$$
0.044
$$

0.073

$-0,004$

$(0.022)$

$(0.024)$

$(0.044)$

$-0.014$

0.104

0.076

$(0.042)$

$(0.044)$

(0.107)

$-0.022$

0.111

0.222

$(0.058)$

$(0.059)$

(0.135)

0.041

$-0.009$

0.021

$(0.031)$

(0.038)

$(0.082)$

$-0.042$

$-0.042$

$-0.054$

$(0.038)$

$(0.044)$

$(0.139)$

$-0.001$

0.000

$-0.005$

$(0.001)$

$(0.001)$

$(0.003)$

$-0.055$

0.045

0.107

$(0.046)$

$(0.047)$

(0.104)

$$
0.051
$$

0.020

0.073

$(0.040)$

$(0.047)$

(0.119)

$-0.001$

$-0.002$

$-0.004$

$(0.005)$

$(0.006)$

$(0.015)$

$$
0.964
$$

0.617

0.866

$(0.108)$

(0.127)

$(0.312)$

0.084

0.203

0.121

246

306

90

1.025

1.014

1.100

The dependent varlable in each equation is the ratlo of the reservation wege to the wage on the last job. Standard errors are shown In parenthesis. 
Table 5

Ef fect of Unemployment Insurance on the Probabllity of a High Reservation Wage

Coefflcient of Unemployment Insurance Varlable to Reservation Wage Ratlo Greater than
1.0
1.1

Job Losers on Layof $f$

$\begin{array}{lcc}\text { Coefficlent } & 0.400 & 0.315 \\ \text { Standard Error } & (0.120) & (0.108) \\ \mathrm{R}^{2} & 0.101 & 0.070 \\ \text { Mean Proportion } & 0.31 & 0.22\end{array}$

Other Job Losers

Coefflclent

0.382

0.421

Standard Error

(0. 108)

$(0.101)$

$\mathrm{R}^{2}$

0.099

0.105

Mean Proportion

0.30

0.24

Job Leavers

Coef fl clent

0.499

0.648

St andard Error

$(0.245)$

$(0.214)$

$\mathrm{R}^{2}$

0.155

0.171

Mean Proportion

0.33

0.26

Each coefficlent is based on equations with the same speclfication as the equations In Table 4 . 


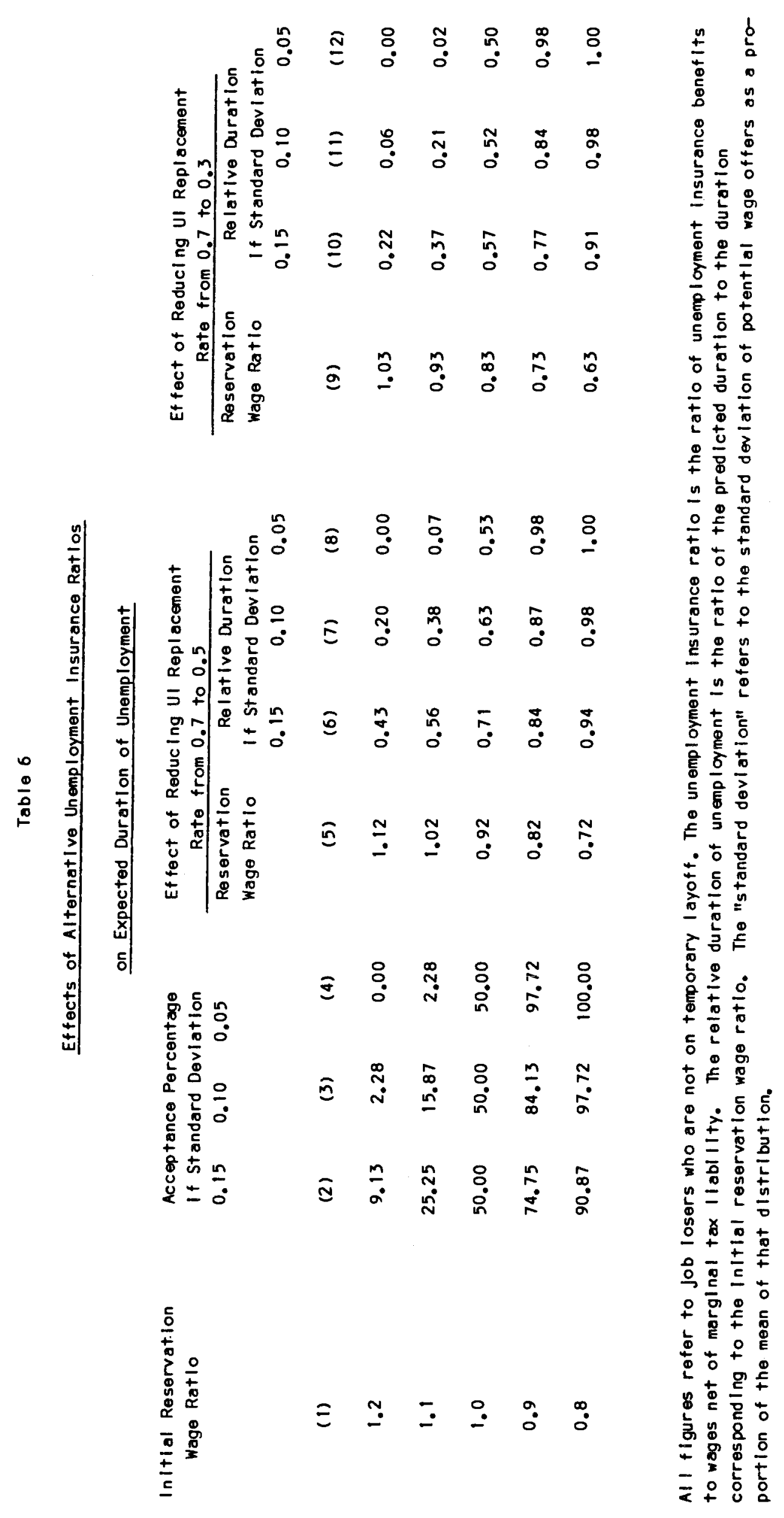

